\title{
Densely Granulated Somatotroph Adenoma
}

National Cancer Institute

\section{Source}

National Cancer Institute. Densely Granulated Somatotroph Adenoma. NCI Thesaurus.

Code C45925.

A growth hormone producing pituitary gland adenoma composed of medium-sized acidophilic cells with granular cytoplasm and abundant secretory granules. 